\title{
Prevalence and antibiotic resistance of the ESBL producing enterobacteria strains isolated in Bologhine hospital during the years 2007-2010
}

\author{
W Amhis', I Boudjelti, N Sahel, L Benbedka, S Benmesbah, W Hamzi \\ From International Conference on Prevention \& Infection Control (ICPIC 2011) \\ Geneva, Switzerland. 29 June - 2 July 2011
}

\section{Introduction / objectives}

To determine the prevalence and the resistance of the extended-spectrum betalactamase (BLSE) producing enterobacteriacea strains in our hospital.

\section{Methods}

All enterobacteriacea strains were screened prospectively between January 2007 and December 2010 for ESBL on the basis of a positive double disk synergy test or positive Ceftazidime and Cefotaxime clavulanic acid combination disks tests. To detect ESBL in the species producing Ampc Betalactamase a modified double disk diffusion test (MDDT) by Pitout et al. was used.

\section{Results}

Among 979 strains isolated during this period, $10.82 \%$ (106) were ESBL producers. These bacteria were isolated in $94.33 \%$ in the inpatients specimens. Their distribution was essentially in the ICU (22.64\%),the surgery $(20.75 \%)$ and the pediatrics $21.21 \%$. They were more frequently isolated from urines $(36.79 \%)$, pus (33\%), peritoneal liquid $(15,15 \%)$ and bacteremia $(12,26 \%)$. This betalactamase was produced by Klebsiella pneumoniae in $60.37 \%$, EÂ .coli in $21.69 \%$ Enterobacter cloacae in $15 \%$. Klebsiella, EÂ. coli and Enterobacter cloacae were also resistant to Fluoroquinolone (28.12\%, 34.78\% and 31.25\%), aminoglycoside $(71.8 \%, 56.52 \%$ and $50 \%)$ and Cotrimoxazole $(28.12 \%, 30.43 \%$ and $31.25 \%)$.

\section{Conclusion}

This study showed that the ESBL producing enterobacteria strains rate is high in our hospital. Other strain than

Laboratoire Central de Biologie, Hôpital Bologhine IBN Ziri Algiers, Algiers, Algeria
Klebsiella and E.coli are expressing ESBL .It is the case of Enterobacter cloacae . So we have to perform the detection of these strains in our laboratory, because these bacteria may function as a reservoir for plasmids carrying ESBL-encoding genes. In front of this situation we have to enhance the hygiene measures in the units were these strains Â were isolated to limit their diffusion.

\section{Disclosure of interest}

None declared.

Published: 29 June 2011

\section{doi:10.1186/1753-6561-5-S6-P136}

Cite this article as: Amhis et al:: Prevalence and antibiotic resistance of the ESBL producing enterobacteria strains isolated in Bologhine hospital during the years 2007-2010. BMC Proceedings 2011 5(Suppl 6): P136.

Submit your next manuscript to BioMed Central and take full advantage of:

- Convenient online submission

- Thorough peer review

- No space constraints or color figure charges

- Immediate publication on acceptance

- Inclusion in PubMed, CAS, Scopus and Google Scholar

- Research which is freely available for redistribution

Submit your manuscript at www.biomedcentral.com/submit
() Biomed Central 